\title{
Gıdayla İlişkili COVID-19 Riskiyle Mücadelede Etkili Gıda Güvenliği Uygulamaları, Gıda İşletmelerinin ve Gıda Çalışanlarının Rolü
}

\author{
Seda Oğur* \\ *Bitlis Eren Üniversitesi, Sağlık Yüksekokulu, Beslenme ve Diyetetik Bölümü, Bitlis, Türkiye, (ORCID: 0000-0002-2041-0790), ogursd@gmail.com
}

(Illk Geliş Tarihi 1 Haziran 2021 ve Kabul Tarihi 15 Ağustos 2021)

(DOI: 10.31590/ejosat.946158)

ATIF/REFERENCE: Oğur, S. (2021). Gıdayla İlişkili COVID-19 Riskiyle Mücadelede Etkili Gıda Güvenliği Uygulamaları, Gıda İşletmelerinin ve Gıda Çalışanlarının Rolü. Avrupa Bilim ve Teknoloji Dergisi, (27), 103-114.

$\ddot{O} \mathbf{z}$

COVID-19 pandemisinin başlangıcında birçok yetkili otorite tarafından SARS-CoV-2'nin gıdalar ve gıda ambalajlarıyla bulaştığına dair kanıt olmadığı bildirilmesine rağmen, gıda ve/veya gidayla temasta olan madde ve malzemelerin enfeksiyonun yayılmasında herhangi bir etkiye sahip olup olmadığı konusundaki endişeler halen sürmektedir. Zaman zaman yapılan çeşitli açıklamalarda virüsün pazarlarda satılan canlı hayvanlar, donmuş ürünler (kırmızı et, tavuk, su ürünleri vb.) tarafından yayılmış olabileceği, gıda ambalajlarında ve işleme yüzeylerinde belirli bir süre canlı kalabileceği belirtilince, COVID-19 pandemisine özel gıda güvenliği uygulamaları ve önlemleri belirli aralıklarla güncellenmiştir. Bu makalede SARS-CoV-2'nin insanlara bulaşmasına sebep olabilecek gıdayla ilişkili faktörler, pandemiyle mücadelede COVID-19'a özgü hijyen ve sanitasyon önlemleri, etkili gıda güvenliği uygulamaları ve pandemi sürecinde söz konusu konularda gıda işletmelerinin ve gıda çalışanlarının rolü ile ilgili güncel bilimsel çalışmalardan bahsedilmeye çalışılmışırı.

Anahtar Kelimeler: COVID-19, Pandemi, Gıda güvenliği.

\section{Effective Food Safety Practices, the Role of Food Businesses and Food Workers in Combating Food-Related COVID-19 Risk}

\begin{abstract}
Despite the fact that at the onset of the COVID-19 pandemic, many authorities reported that there was no evidence of SARS-CoV-2 being transmitted through foods and food packaging, concerns still remain as to whether food and/or food contact substances and materials have any effect on the spread of the infection. Food safety practices and precautions specific to the COVID-19 pandemic were updated certain intervals, when it was stated in various statements made from time to time that the virus may be spread by live animals sold in markets, frozen products (red meat, chicken, seafood etc.), could remain alive on food packaging and processing surfaces for a certain period of time. In this article have been mentioned from current scientific studies on food-related factors that may cause SARSCoV-2 to be transmitted to humans, COVID-19-specific hygiene and sanitation measures in combating the pandemic, effective food safety practices, and the role of food businesses and food workers in the aforementioned issues and in the pandemic process.
\end{abstract}

Keywords: COVID-19, Pandemic, Food safety.

\footnotetext{
*Sorumlu Yazar: ogursd@gmail.com
} 


\section{Giriş}

Aralık 2019'da, Çin'de yeni bir zoonotik hastalık salgını olarak başlayan yeni tip koronavirüs (COVID-19), dünyanın birçok ülkesine hızla yayıldıktan sonra 11 Mart 2020'de Dünya Sağlık Örgütü (DSÖ) tarafından pandemi olarak ilan edilmiştir (WHO, 2020a). COVID-19'a SARS-CoV-2 beta-koronavirüs neden olmakta (WHO, 2020b), virüse maruziyetten 2-14 gün sonra semptomlar (ateş, öksürük, nefes darlığı, boğaz ağrısı, kas ağrıları (CDC, 2020a), tat ve koku kaybı (Bienkov, 2020)) gelişmektedir. Enfeksiyonların çoğu hafif olmasına rağmen, ilk raporlara göre vakaların \%16'sında ciddi şekilde yaşamı tehdit eden hastalık geliştiğinden (NEHA, 2020) birçok ülkede virüsün bulaşma hızını azaltmak için tam veya kısmi kapanma uygulanmıştır.

Gıda; sağlık, enerji, iletişim sektörlerinin yanı sıra bir ülkenin kritik altyapısının bir parçası olarak kabul edildiğinden pandemi sırasında normal operasyonun sürdürülmesi gerekmektedir (CISA, 2020).

COVID-19 salgınının insanlar aracılığıyla yayılımının önüne geçilmesinde en büyük etken olan sosyal mesafenin sağlanması amacıyla bazı sektörlerde çalışan sayısının azaltılması, üretimin durdurulması gibi uygulamalara geçilirken şartları elverişli olan sektörlerdeki çalışanlar evlerinden çalışmaya başlamıştır. Gıda sektöründeki restaurant, cafe vb. küçük işletmelerde tam kapanma nedeniyle paket servis ve gel-al şeklinde satışa geçildiğinden dolayı eleman sayısı azaltılırken fabrika düzeyinde üretim yapan birçok işletmede ek önlemler alınarak (veya alınmaya çalışılarak) çalışanlar mevcut yerlerinde çalışmaya devam etmiştir. Hatta oluşan panik nedeniyle bazı gıdalarda stoklama yoluna gidilince, aynı çalışan sayısıyla stoklanan gıda ürünlerinin üretim miktarı arttırılmıştır. Bu işletmelerdeki gıda çalışanları daha uzun süre ve bazen izin kullanmadan çalışmak zorunda kalmıştır.

Türkiye'deki ulusal bir yayın organının 27/03/2020 tarihli haberinde, Türkiye Gıda Sanayi İşçileri Sendikası (Gıda-İş)'nın gıda sektöründe faaliyet gösteren işletmelerden 150-4000 arasında işçi çalıştıran 45 işyerinde alınan koronavirüs tedbirlerini inceleyerek alınmayan önlemlerden oluşan bir rapor hazırladığ 1 bildirilmiştir. Raporda işletmelerin \%70'inde üretimin arttığ1, artan üretimin yine aynı sayıdaki işçilerle yapılması sebebiyle işçilerin çalışma saatlerinin uzadığı, işçilerin büyük çoğunluğunun kendilerini koronavirüse karşı güvende görmediği belirtilmiştir. İşletmelerde eldiven, maske vb. koruyucu malzemelerin yetersiz olduğu, bazı işletmelerde sabun, kağıt havlu vb. temizlik malzemelerinin yeterince bulunmadığı, üretim sürecinde sosyal mesafenin korunmadığı, işletmelerin \% 75 'inde yemekhaneler, soyunma odaları gibi alanların dezenfekte edilmediği ya da bu işlemin olması gerektiği gibi değil, göstermelik olarak yapıldığı, firınların, pastanelerin ve ekmek satış büfelerinin \%80'inde hijyen ve dezenfeksiyon koşullarına uyulmadığı ortaya çıkan bazı sonuçlar olmuştur. Bir işletmede, özel istihdam bürolarından paketleme, depolama ve makine temizliği için günlük olarak yevmiyeci işçi çalıştırılması ise dikkat çeken başka bir tespit olmuştur (Evrensel, 2020a).

Pandemi sürecinde gida güvenliği yönetiminin sağlanmasında gıda çalışanlarının rolünün ne kadar önemli olduğu tartışılmazdır. Hammadde kabulünden nihai gıda ürününün son tüketiciye ulaşmasına kadar geçen bütün e-ISSN: 2148-2683 aşamalarda COVID-19 riskinin oluşmaması ve her koşulda güvenli gidaların üretilmesi onların elindedir. $\mathrm{Bu}$ sebeple uluslararası kuruluşlar, ulusal hükümetler ve yerel yöneticilerce hazırlanan kılavuzlarla gıda çalışanlarının COVID-19 pandemisindeki hastalık belirtileri, yayılım yolları, temel hijyen kuralları dışındaki bu hastalığa özel hijyen kuralları, işletme içinde alınması gereken özel önlemler, nakliye ve dağıtımda alınacak tedbirler, perakende satış yerlerinde alınması gereken tedbirler vb. konularda eğitilmeleri ve bilinçlendirilmeleri amaçlanmıştır.

Pandeminin ilk dönemlerindeki tarihlerde yapılan açıklamalarda (FDA, 2020a; WHO, 2020a; EFSA, 2020, ISDH, 2020) COVID-19'un gidalar ve gida ambalajlarıyla bulaştığına dair kanıt olmadığı bildirilmiştir. ABD Gıda ve İlaç Dairesi (FDA) 27/02/2020 tarihli bildirisinde COVID-19'un gida ya da gida ambalajı yoluyla bulaşabileceğini gösterir bir bilginin henüz olmadığını, ancak iyi hijyen uygulamalarının sağlanmasının bütün hastalıklardan korunmada her zaman önemli olduğu hususunu ifade etmiştir (FDA, 2020a). Dünya Sağlık Örgütü (DSÖ) 21/02/2020 tarihli raporunda COVID-19'un etkeni olan SARS-CoV-2 virüsünün gıda aracılığıyla bulaştığına dair bir kanıtın olmadığını, fakat benzer virüslerin ve bu virüsün de hayvansal kaynaklı çiğ gıdalarda bulunabileceği konusunda şüpheler olduğunu bildirmiştir (WHO, 2020a). Avrupa Gıda Güvenliği Otoritesi 08/04/2020 tarihli raporunda pandeminin büyük ölçekli olmasına rağmen, o güne kadar COVID-19'un gıda tüketimi yoluyla bulaşmasıyla ilgili herhangi bir rapor olmadığını belirtmiştir (EFSA, 2020).

AB Üye Devletleri'ndeki (Avustralya, Belçika, Bulgaristan, Hırvatistan, Kıbrıs, Çekya, Danimarka, Estonya, Finlandiya, Fransa, Almanya, Yunanistan, Macaristan, İrlanda, İtalya, Letonya, Litvanya, Lüksemburg, Malta, Hollanda, Polonya, Portekiz, Romanya, Slovakya, Slovenya, İspanya, İsviçre) ajanslar gıda işlemeden COVID-19'u almanın mümkün olmadığını ifade etmiştir (EC, 2020). ABD Indiana Eyaleti Sağlık Bakanlığı 19/03/2020 tarihli raporunda COVID-19'un gidanın kendisi ya da ambalajı ile bulaşabileceğini öneren insan hastalıklarının herhangi bir raporunun şu anda farkında olmadıklarını bildirmiştir (ISDH, 2020).

Ancak sonraki aylarda yapılan bilimsel çalışmalarla (Middleton vd., 2020; Chin vd., 2020; Van Doremalen vd., 2020; Riddell vd., 2020; Harbourt vd., 2020, Kratzel vd., 2020; Pastorino vd., 2020; Oakenfull ve Wilson, 2020; Dyal vd., 2020; Blondin-Brosseau vd., 2020; Han vd., 2021; Matson vd., 2020) COVID-19 etkeni SARS-CoV-2'nin gida ürünleri, gida ambalajları ve gıda zinciri aracılığıyla ne şekilde taşınabileceği, gıda ve ilişkili faktörlerin (hammadde tedariği, personel, işleme yüzeyi ve yöntemi, dezenfeksiyon ve sanitasyon uygulamaları, ambalaj, nakliye vb.) hastalığın bulaşmasındaki ve yayılımındaki etkinliklerinin nasıl olduğu açıklanmıştır.

SARS-CoV-2'nin potansiyel gida yoluyla bulaşmasının, enfekte hayvanlardan kaynaklanan gıdaların veya çapraz kontamine gıdaların tüketiminden kaynaklanabileceği öne sürülmüştür (Oakenfull ve Wilson, 2020).

Nakat ve Bou-Mitri (2021) pandeminin ilan edilmesinden itibaren COVID-19 ve gida ile ilgili kavramlar (gıda endüstrisi, gıda güvenliği, tedarik zinciri, gıda güvencesi vb.) konularıyla ilişkili çalışmaların sayısının hızla arttığını gözlemlediklerini 
belirtmiştir. Bu sonucun, COVID-19 ve gıda ilişkisi konusunun acil bir öncelik olduğunu, yeni normlar ve yönergeler geliştirmek için hızlandırılmış araştırmalara ihtiyaç duyulduğunu gösterdiği bildirilmiştir (Nakat ve Bou-Mitri, 2021).

$\mathrm{Bu}$ makalede COVID-19 enfeksiyonunun yayılımını tetikleyebilecek gıdayla ilişkili faktörlerden, yeni tip koronavirüsle mücadelede pandemiye özgü hijyen ve sanitasyon önlemlerinden, etkili gıda güvenliği uygulamalarından ve bu konularla ilgili pandemi sürecinde gıda işletmelerinin ve gıda çalışanlarının rolü hakkında bilgi veren güncel çalışmalardan bahsedilmiştir.

\section{SARS-CoV-2'nin Gıda ve Gıda İşçileri ile İlgili Bulaşma Yollarına İlişsin Kanıtlar}

Bir virüs tarafından gıda kontaminasyonunun genellikle şu şekillerde gerçekleştiği belirtilmiştir: Kabuklu deniz hayvanlarının büyüdüğü suyun veya hasattan sonra meyveyi yıkamak için kullanılan suyun kontaminasyonunu içerebilen üretim süreci sırasında, iyi hijyen uygulamalarına uymayan enfekte gıda işleyicileri tarafından veya zoonotik virüs içeren hayvansal kaynaklı ürünlerin tüketilmesiyle (Velebit vd., 2019).

Mevcut salgının merkez üssünün, hem canlı hem de doğrudan tüketim için çeşitli memeli hayvanların satıldığı Wuhan Deniz Ürünleri-Yaban Hayatı Hayvan Pazarı olduğu tescillendiğinden (Lam vd., 2020) çiftlik hayvanlarına SARS-CoV-2'nin bulaşması ve enfeksiyon sonucunda hayvan kaynaklı gıdalarda virüsün yayılmasıyla ilgili endişeler bulunmaktadır. Sığırlarda virüs replikasyonu ve serokonversiyonu gösterilmiştir, ancak sütte virüsün olası varlığı hakkında herhangi bir veri henüz mevcut değildir (Costa vd., 2020).

DSÖ’nün SARS-CoV-2'nin kaynağının tespit edilmesi amacıyla Wuhan kentinde yürüttüğü son çalışmalarla (2021 Ocak ayı ortalarında başlayıp yaklaşık 1 ay süren incelemeler) ilgili heyet başkanı ve gıda güvenliği uzmanı olan Peter Ben Embarek yaptığı açıklamada, virüsün insanlara nasıl geçtiğini bulmaya yönelik incelemelerinin dört teze odaklandığını söylemiştir. Embarek bu olasılıkları şöyle sıralamıştır: 1. Virüsün doğrudan hayvanlardan geçmesi, 2. Virüsün hastalığı taşıyıcı hayvan türlerinden bulaşması, 3. Virüsün donmuş ürünler yoluyla geçmesi, 4. Virüsün Wuhan'daki laboratuvardan yayılması. Peter Ben Embarek komplo teorilerinin odağında yer alan laboratuvar tezinin aşırı derecede düşük bir ihtimal olduğunu, daha fazla çalışma yapılması gerekse de ilk bulgulara göre ilk olası seçeneğin virüsün taşıyıcı bir hayvan üzerinden insanlara geçmiş olması olduğunu belirtmiştir. Ancak heyet virüsün hayvandan hayvana bulaştığına dair kanıtlara rastladıklarını bildirmiş olsa da, kamuoyu virüsün asıl kaynağının tespiti için çok geç kalındığını, bu kanıtın şu an için hiçbir şey ifade etmediğini belirtmiştir (BBC News, 2021).

DSÖ yaptığı incelemeler sonucunda canlı hayvan pazarlarının COVID-19 gibi bulaşıcı hastalıkların ortaya çıkmasına neden olabileceğini, bu tip yerlerin sağlık için risk yarattığını, özellikle vahşi hayvanların (vahşi memeliler) çoğunun yeni virüslerin ortaya çıkmasına neden olan tüm bulaşıcı hastalıkların \%70'inden fazlasının kaynağı olduğunu açıklamıştır ve bu tip canlı hayvan pazarlarının acil olarak kapatılması çağrısında bulunmuştur. Bunun üzerine Birleşmiş Milletler Sağlık Kurumu 13/04/2021'de vahşi hayvanların koronavirüs gibi yeni ortaya çıkan bulaşıcı hastalıkların önde gelen kaynağı olduğunu söyleyerek, ülkeleri gıda pazarlarında doğadan yakalanan canlı hayvanların satışını acil bir önlem olarak askıya almaya çağırmıştır (AP News, 2021).

Gıda tesislerindeki işçiler arasında COVID-19 salgınları meydana gelince hem tüketiciler hem de üreticiler gida ürünlerinden endişe duymuştur. Örneğin; Temmuz 2020'de Çin, yeni vakaların varlığının SARS-CoV-2 salgınlarına karışan gıda paketleme ve işleme tesislerinden gida ithalatıyla bağlantılı olduğunu değerlendirerek birçok ülkeden karides, somon, tavuk ve diğer donmuş gıda ithalatını askıya almıştır (Pang vd., 2020; Shenzhen Government, 2020). Ancak, SARS-CoV-2, Coronaviridae ailesinin ve sadece memelileri enfekte eden Betacoronavirus cinsinin bir parçası olduğu için (Lam vd., 2020), bu nedenle somon balığının COVID-19'un insanlara uygun işleme ve sanitasyon süreciyle yayılmasında epidemiyolojik rolü olmasının olası olmadığı ileri sürülmüştür (Bondad-Reantaso vd., 2020).

SARS-CoV-2'nin esas olarak insandan insana, genellikle enfekte olduğunda, öksürüp hapşırdığında salgılanan solunum damlacıkları yoluyla yayıldığı (Leung vd., 2020), damlacıklar genellikle hava akımı ile taşındığı ve birkaç metre içinde düştüğü için, insanlar en az 2 m uzakta kalırsa bulaşma olasılığının azaldı $\breve{g} 1$ belirtilmektedir (CDC, 2020b; IDFA, 2020). Bu sebeple bir kişinin bir gıda veya gıda ambalajı ya da gıdanın işlendiği tezgah yüzeyine veya gidayla ilişkili herhangi bir nesne üzerindeki kontamine damlacıklara dokunduktan sonra kendi yüzüne, ağzına, burnuna veya gözlerine dokunmasıyla COVID19 kapmasının mümkün olabileceği bildirilmiştir (Şekil 1) (WHO, 2020b).

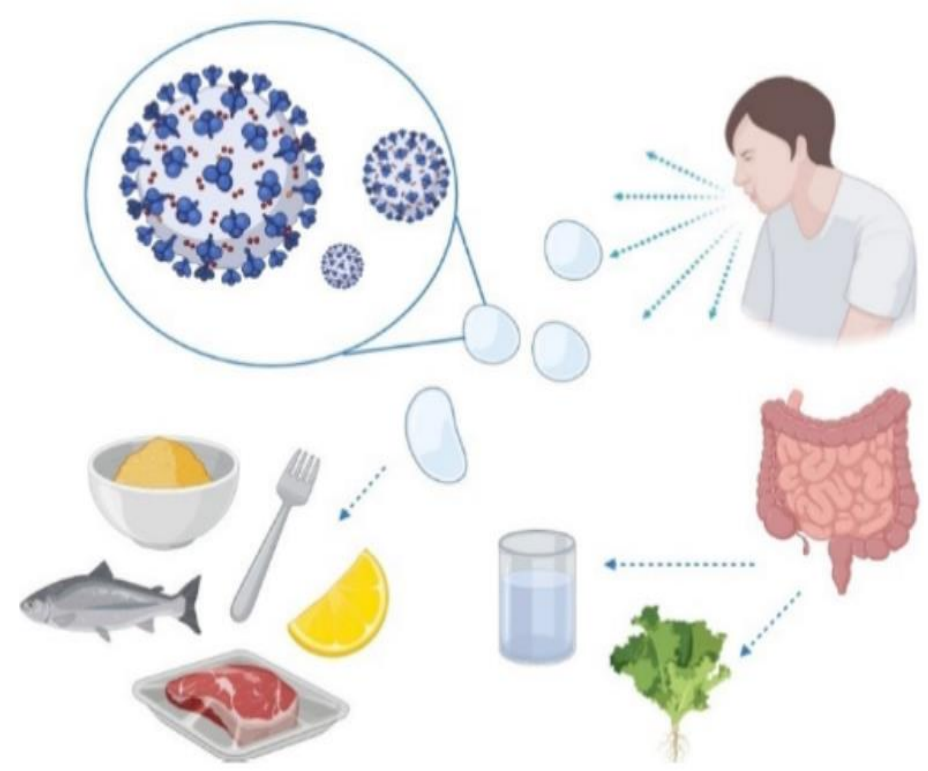

\section{Şekil 1. SARS-CoV-2'nin Gıda veya Gldayla İlişkili Kaynaklar ile Bulaşması}

Mutfaklardaki gıda işleme uygulamalarıyla ilgili olarak, koronavirüslerle elde edilen kanıtlar pişirmede hayatta kalamayacaklarını, ancak yiyecekler yıkanmadan kalırsa ve daha sonra dondurulursa, virüsün dondurulmuș depolama sırasında 2 y1la kadar hayatta kalabileceğini göstermiştir (BfR, 2020).

Harbourt vd. (2020), SARS-CoV-2'nin domuz derisinde 37 ${ }^{\circ} \mathrm{C}$ 'de 8 saat, $22{ }^{\circ} \mathrm{C}$ 'de 96 saat ve $4{ }^{\circ} \mathrm{C}$ 'de 14 gün boyunca stabil kaldığını bulmuştur. Blondin-Brosseau vd. (2020) SARS-CoV2 'nin elma ve domateslere aşılandıktan sonra 24. saatte virüs 
tespit edilmediğini, salatalıklarda aşılamadan 72 saat sonra bulaşıcılığını sürdürdüğünü kanıtlamışlardır.

Pung vd. (2020), üç COVID-19 kümesini bir konferans sırasında paylaşılan yemek uygulamasına bağlamış ve bilimsel topluluk COVID-19'un gida yoluyla bulaşmasına yeniden odaklanmıştır (Han vd., 2021; Rizou vd., 2020).

Koronavirüslerin fekal-oral yolu domuz (Niederwerder ve Hesse, 2018), köpek (Decaro vd., 2009) ve sığır (Hasoksuz vd., 2007) gibi birçok hayvanda gösterildiğinden, kontamine gida ve/veya suyun yutulması yoluyla bulaşma ihtimalinin olabileceği belirtilmiştir (Bosch vd., 2018).

Bu kanıtların 1şı̆̆ında, gıda zinciri yoluyla olası bulaşma ile ilgili endişeler son aylarda artmıştır. Ancak, kontamine gıda tüketimi ile hastalık arasında sabit bir bağlantı olmadığından SARS-CoV-2'nin gida kaynaklı bir virüs olarak kabul edilemeyeceği bildirilmiştir (Ceniti vd, 2021).

SARS-CoV-2'nin insanlara giriş için bir alıcı olarak anjiyotensin dönüştürücü enzim 2 (ACE2)'yi kullandığı (Walls vd., 2020) ve viral reseptör ACE2'nin gastrointestinal epitel hücrelerinde bol miktarda eksprese edildiği bulunmuştur (Xiao vd., 2020). Bu bulgular, virüsün sindirim sisteminde var olabileceğini ve çoğalabileceğini göstermektedir, ancak SARSCoV-2 ile kontamine gida yemenin enfeksiyona neden olup olmadığ net değildir (Wong vd., 2020; Mungroo vd., 2020). Xiao vd. (2020) tarafından, fekal-oral geçiş viral yayılma için ek bir yol olabileceğinden virüsün yayılmasını kontrol etmek için fekal-oral geçişin önlenmesinin dikkate alınması gerektiği belirtilmiştir.

Dışkı atımı gösterilmiş olmasına rağmen (Van Doorn vd., 2020; Wu vd., 2020; Hu vd., 2020; Hindson, 2020), bugüne kadar esas olarak insan sindirim sisteminde meydana gelen bir enfeksiyon rapor edilmediğinden, gerçek bir fekal-oral yol kanıtlanmadığı ifade edilmiştir (Ceniti vd., 2021).

Enfekte bir g1da işçisinin virüsü kontamine gıda veya gıda ambalaj malzemesi yerine kişiden kişiye bulaşma yoluyla yaymasının daha olası ve COVID-19'un, gıda kirliliğinden çok iş güvenliği ve çalışan sağlığının korunmasıyla ilgili bir sorun olduğu belirtilmiştir (OSHA, 2020a). Ancak, toplumların büyük çoğunluğunda olduğu gibi, birçok ülkedeki gıda işçileri de COVID-19'a maruz kalmış ve bu maruziyetin bir süre daha devam edeceği görülmektedir.

ABD'de en az 462 et paketleme tesisinin, 257 gıda işleme tesisinin, 93 çiftlik ve üretim tesisinin ülkedeki COVID-19 vakalarından etkilendiği, en az 54.036 işçinin (39.905 et paketleme işçisi, 8.343 gıda işleme işçisi, 5.788 çiftçi) COVID19 pozitif olarak tanımlandığ 1 ve en az 232 işçinin (184 et paketleme işçisi, 34 gıda işleme işçisi, 14 çiftlik işçisi) hayatını kaybettiği rapor edilmiştir (Douglas, 2020).

Brezilya'da 18 belediyedeki 24 mezbahadan 2.400 et tesisi işçisi COVID-19 pozitif olarak belirlenmiştir. İngiltere ve Galler'deki birkaç et fabrikası, 246 pozitif vakanın ardından faaliyetlerini durdurmuştur. Gana'da bir balık işleme fabrikasındaki 534 personel virüs pozitif çıkmıştır. Almanya'daki et işleme tesislerinde 1.553 COVID-19 vakası bulunmuştur ve Fransa'daki mezbahalarda 100'den fazla koronavirüs enfeksiyonu kaydedilmiştir (BBC, 2020; Gulland, 2020; Kaur, 2020; Ziady vd., 2020).

ABD Hastalık Kontrol ve Önleme Merkezi (CDC), 19 eyaletteki 115 et ve kümes hayvanı işleme tesisinde $\mathrm{ABD}$ işçileri arasında 4.913 COVID-19 vakası ve 20 ölüm bildirmiştir (Dyal e-ISSN: 2148-2683 vd., 2020). Enfeksiyon riskini potansiyel olarak etkileyen tanımlanmış faktörlerin işyerinde fiziksel mesafe, hijyen, kalabalık yaşam ve ulaşım koşullarındaki zorluklar olduğu belirtilmiştir (CDC, 2020c; Dyal vd., 2020).

Nisan-Mayıs 2020'de 23 ABD eyaletinde bulunan 239 et ve kümes hayvanı işleme tesisinde işçiler arasında 16.233 vaka ve 86 COVID-19 ölümü olduğu rapor edilmiştir (Waltenburg vd., 2020). Et ve deniz ürünleri işleyen işçilerde SARS-CoV-2'ye maruz kalma riskinin artmasıyla ilgili faktörlerin; iş arkadaşlarına uzun süreli yakınlık (örn. $\geq 15$ dakika için $1,8 \mathrm{~m}$ ), uzun süreler (et işlemede 8-12 saatlik vardiya ve deniz ürünleri işlemede 8-16 saatlik vardiya) paylaşılan çalışma alanları, iş arkadaşlarıyla sık sık iletişim teması, paylaşılan ulaşım araçları ve toplu konutlar olduğu bildirilmiştir (CDC, 2020d; Waltenburg vd., 2020).

Balık ve deniz ürünleri endüstrisinde, toplu konutlarda ve gemilerdeki kalabalıktan dolayı enfeksiyon riski artmış olan mevsimlik işçilerin de bulunduğu (CDC, 2020d), tarımsal endüstri çalışanlarının da aynı risklere maruz kaldığı ifade edilmiştir (CDC, 2020e).

DİSK/Gıda-İş Sendikası, Türkiye'de 27 Mart-17 Nisan 2020 tarihleri arasında 40.000 gıda işçisinin çalıştığı 58 fabrikanın 17'sinde 362 pozitif vakanın çıktığını, işletmelerin \%70'inde üretimin artmış olarak aynı ya da azalan sayıdaki işçilerle sürdüğünü ve işletme sorumlularınca işçilerin COVID-19'dan korunması için gerekli önlemlerin yeterince alınmadığını bildirmiştir (Evrensel, 2020b). Ancak salgının başlangıcından bu güne kadar Türkiye'deki kaç gıda işçisinin koronavirüse yakalandığı ve bunda etken olan faktörlerin tam olarak neler olduğu ne yazık ki halen belirsizdir.

\section{SARS-CoV-2'nin Gıda ile İlişkili Çevre ve Yüzeylerdeki Varlığına İlişskin Kanıtlar}

Aboubakr vd. (2020) SARS-CoV-2'nin 3-16 saat arasında aerosellerde bulaşıcı göründüğü, oda sıcaklığında ve $\% 65$ bağıl nemde birkaç gün hayatta kalabildiği sonucuna vararak havadan iletim olasılığı olabileceğini bildirmiştir. $\mathrm{Bu}$ durumda, gıda işletmelerinde COVID-19 ile enfekte personelin zamanında tespit edilememesi durumunda solunum yoluyla yayılan aerosellerin olduğu ortam havasının COVID-19'un taşınmasında etkili olabileceği söylenebilir.

Guo vd. (2020) SARS-CoV-2'nin, Çin'in Wuhan kentinde yoğun bakım ve genel COVID-19 hastane servislerinde havada ve yüzeylerde yaygın olarak dağıldığı sonucuna vararak SARSCoV-2'nin iletim mesafesinin $4 \mathrm{~m}$ olabileceğini göstermiştir. Ayrıca virüsün aerosollerde saatlerce ve yüzeylerde günlerce canlı ve bulaşıcı kalabildiği de tespit edilmiştir (Van Doremalen, 2020). Gıda işletmelerindeki personelin SARS-CoV-2 taşıma olasılığının her zaman olabileceği göz önünde bulundurularak üretim sırasında sosyal mesafenin sağlanmasının oldukça önemli olduğu görülmektedir.

Yapılan bir çalışmada (Van Doremalen, 2020) hem SARSCoV-1'in hem de SARS-CoV-2'nin bakır yüzeylerde 8 saat sonra büyük ölçüde azalmış olsa da, plastik yüzeylerde 72 saat sonra tespit edildiği belirtilmiştir. Chin vd. (2020)'nin araştırmasında 7. günde cerrahi maskenin dışında tespit edilip baskı kağıdı ve kağıt mendil üzerinde 3 saatlik inkübasyondan sonra geri kazanılmazken, işlenmiş ahşaptan ancak 1. günden sonra, 
plastikte, paslanmaz çelikte ve banknotlarda ancak 4. günden sonra tespit edilmemiştir (Chin vd., 2020).

Ancak farklı çevresel koşullara ve sıcaklıklara maruz kalmış kontamine gıda ambalajlarının enfeksiyonu taşıdığına dair hala bir kanıt olmadığ
Tablo 1'de SARS-CoV-2'nin gida ile temas edebilecek farklı yüzeylerdeki stabilitesiyle ilgili yürütülmüş çalışmalar özetlenmiştir (Ceniti vd., 2021).

Tablo 1. SARS-CoV-2’nin Gıda ile Temas Edebilecek Farklı Yüzeylerdeki Stabilitesiyle İlgili Yürütülmüş Çalışmalar

\begin{tabular}{|c|c|c|c|c|}
\hline Yüzey & Virüsün Tespit Süresi & Ortam Koșulları & Virüs Yükü & Referans \\
\hline Plastik & $72 \mathrm{~s}$ & \multirow{4}{*}{$\begin{array}{c}21-23{ }^{\circ} \mathrm{C}, \% 40 \text { nispi } \\
\text { nem }\end{array}$} & \multirow{4}{*}{$10^{5,25} \mathrm{TCID}_{50} / \mathrm{L}$ hava } & \multirow{4}{*}{$\begin{array}{c}\text { Van Doremalen vd. } \\
\text { (2020) }\end{array}$} \\
\hline Bakır & $4 \mathrm{~s}$ & & & \\
\hline Karton & $24 \mathrm{~s}$ & & & \\
\hline Paslanmaz çelik & $72 \mathrm{~s}$ & & & \\
\hline Cam & 2 gün & \multirow{4}{*}{$22{ }^{\circ} \mathrm{C}, \% 65$ nispi nem } & \multirow{4}{*}{$10^{7,8} \mathrm{TCID}_{50} / \mathrm{mL}$} & \multirow{4}{*}{ Chin vd. (2020) } \\
\hline Ahşap & 1 gün & & & \\
\hline Paslanmaz çelik & 4 gün & & & \\
\hline Plastik & 4 gün & & & \\
\hline Paslanmaz çelik & 28 gün/7 s/48 s & \multirow{4}{*}{$\begin{array}{c}20{ }^{\circ} \mathrm{C} / 30{ }^{\circ} \mathrm{C} / 40{ }^{\circ} \mathrm{C}, \\
\% 50 \text { nispi nem }\end{array}$} & \multirow{4}{*}{$\begin{array}{l}4,97 \times 10^{7} / \mathrm{mL} \text { standart } \\
\text { solüsyona dilüe edilmiş }\end{array}$} & \multirow{4}{*}{ Riddell vd. (2020) } \\
\hline Cam & 28 gün/7 s/48 s & & & \\
\hline Pamuk & $\begin{array}{l}14 \text { gün } / 3 \mathrm{~s} / \text { tespit } \\
\text { edilmedi }\end{array}$ & & & \\
\hline Vinil & 28 gün/3 s/48 s & & & \\
\hline $\begin{array}{l}\text { Deri örnekleri (Sus } \\
\text { scrofa) }\end{array}$ & 14 gün/96 s/8 s & \multirow[b]{2}{*}{$4{ }^{\circ} \mathrm{C} / 22{ }^{\circ} \mathrm{C} / 37^{\circ} \mathrm{C}$} & \multirow{2}{*}{$\begin{array}{c}0,01 \text { 'in enfeksiyon } \\
\text { çokluğunda } \\
\text { (multiplicity of } \\
\text { infection) Vero } 76 \\
\text { böbrek hücreleri }\end{array}$} & \multirow[b]{2}{*}{ Harbourt vd. (2020) } \\
\hline Kumaş & $96 \mathrm{~s} / 4 \mathrm{~s} / 4 \mathrm{~s}$ & & & \\
\hline Metal yüzey & $180 \mathrm{~s}$ & $\begin{array}{l}4{ }^{\circ} \mathrm{C} / 30{ }^{\circ} \mathrm{C}, \% 30-40 \\
\text { nispi nem, } 1 \text { s kurutma }\end{array}$ & $9,6 \times 10^{4} \mathrm{TCID}_{50} / \mathrm{mL}$ & Kratzel vd. (2020) \\
\hline Cam & \multirow{3}{*}{$96 \mathrm{~s}$} & \multirow{3}{*}{$\begin{array}{c}19-21{ }^{\circ} \mathrm{C}, \% 45-55 \text { nispi } \\
\text { nem }\end{array}$} & \multirow{3}{*}{$10^{6} \mathrm{TCID}_{50} / \mathrm{mL}$} & \multirow{3}{*}{ Pastorino vd. (2020) } \\
\hline Polistiren plastik & & & & \\
\hline Alüminyum & & & & \\
\hline
\end{tabular}

Kratzel vd. (2020)'nin çalışmasında inoküle edilen virüs titresi $\left(9,6 \times 10^{4} \mathrm{TCID} 50 / \mathrm{mL}\right) 4{ }^{\circ} \mathrm{C}$ 'de 8 saat stabil kalırken 30 ${ }^{\circ} \mathrm{C}$ 'ye kadar olan sicaklıkların virüsün mutlak inaktivasyonunu sağlamadığı gösterilmiştir. SARS-CoV-2 bulaşıcılığının kurutma işlemi sırasında büyük ölçüde azalmasına rağmen, kuru halde birkaç gün boyunca bulaşıcı kaldığını vurgulamışlardır (Kratzel vd., 2020). Soğuk sıcaklıkların incelendiği çalışmalarda (Han vd., 2021; Matson vd., 2020) SARS-CoV-2'nin düşük sıcaklıklarda yüksek stabilite gösterdiği bildirilmiştir.

Soğuk sıcaklıklar genellikle gıdaların muhafazasında ve nakliyesinde uygulandığı için soğuk zincir enfeksiyonu aktarmanın olası bir yolunu temsil edebileceğinden bu kanıtın ciddi bir risk teşkil ettiği belirtilmiştir (Ceniti vd., 2021). Şekil 2 SARS-CoV-2'nin sıcaklığa göre nasıl davrandığına ilişkin kanıtları özetlemektedir (Ceniti vd., 2021).

Gıda işleme tesislerinin içindeki soğuk ve nemli ortamın, COVID-19'un yayılmasını kolaylaştıran bir başka faktör olduğu ve ultraviyole 1 şığın olmadığı soğuk ve karanlık ortamların koronavirüsü canlı tutması ve bulaşma oranlarında artışa neden olmasının mümkün olduğu bildirilmiştir (Artiga ve Rae, 2020; Gulland, 2020).
4. COVID-19 Enfeksiyonu Riskinin Azaltılmasında Etkili Olduğu Belirtilen Gıda Güvenliği Uygulamaları, Gıda İşletmelerinin ve Gıda Çalışanlarının Dikkat Etmesi Gereken Hususlar

Pandemi sürecinde temel gıda güvenliği uygulamalarından bazıları (el hijyeninin ve işletme içi sanitasyonun sağlanması) yeniden gündeme gelirken, bunlara ilave olarak COVID-19 enfeksiyonuna özel gıda güvenliği uygulamaları (fiziksel mesafenin korunması, enfeksiyona özel kișisel koruyucu ekipman (KKE)'ların kullanımında dikkat edilmesi gerekenler, enfeksiyon etkeninin dezenfeksiyonunda kullanılması gereken dezenfektanlar, işletme içerisindeki çevre ve ortak alanların yönetiminde dikkat edilecek hususlar vb.) da ortaya çıkmıştır (OSHA, 2020; WHO, 2020d; WHO, 2020e; WHO, 2020f; Angell, 2020; WHO, 2020g; CDC, 2020f; IDFA, 2020; CDC, 2020g; CDC, 2020h). 


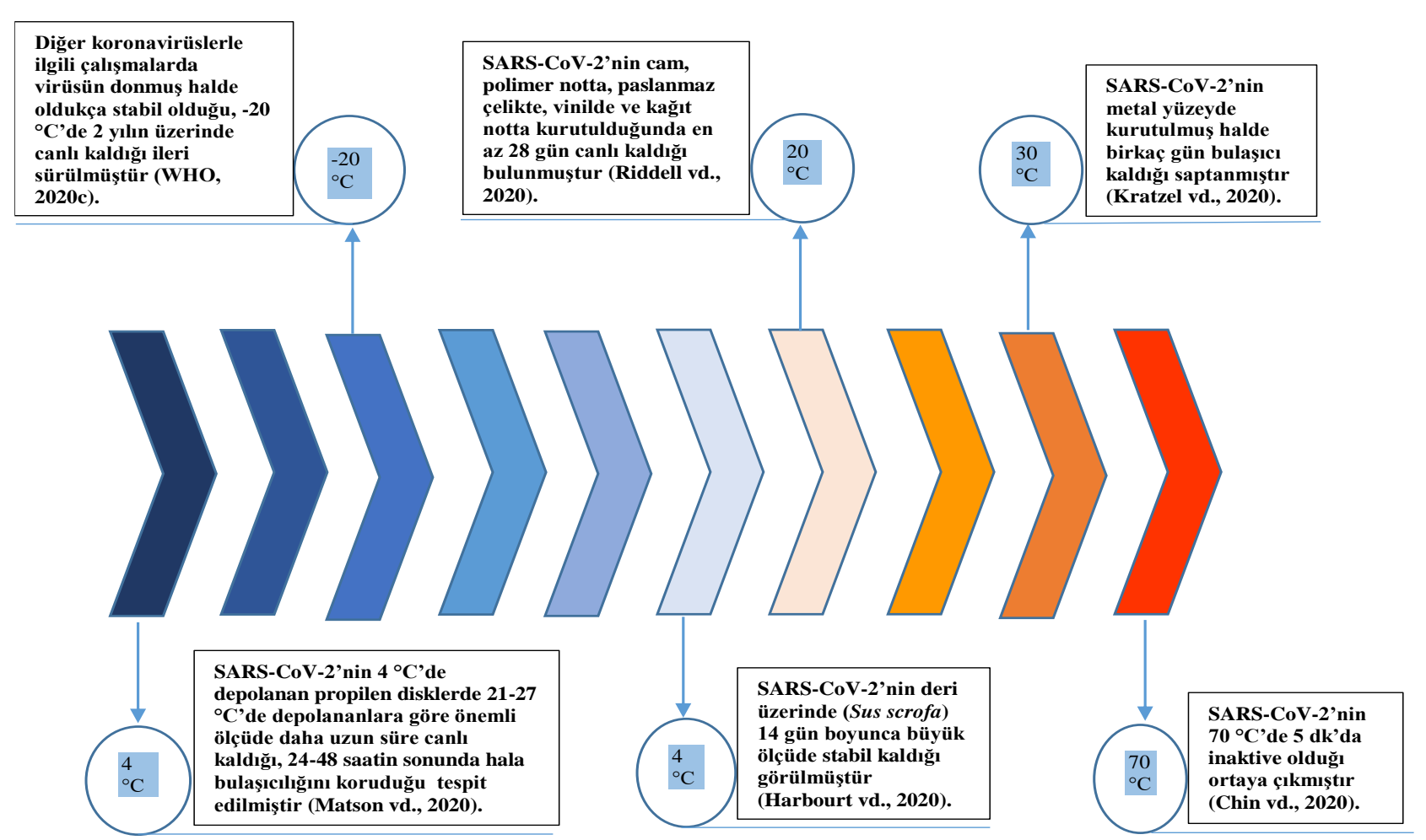

Şekil 2. Koronavirüslerin, SARS-CoV-2'nin Farklı Sıcaklıklarda Canlılı̆̆ına İlişkin Kanıtlar

Hijyen önlemlerinin güçlendirilmesinin ve gıda hijyeni ilkeleri hakkında yeniden eğitim verilmesinin, gıda çalışanlarının virüsle kontamine olma riskinin ortadan kaldırılması veya azaltılması için gerekli olduğu belirtilmiştir (WHO, 2020h). Eğitim, etkili ve sürekli iletişim uygun COVID-19 önlemleri için temel taş olarak kabul edilmiştir (BSI Group, 2020). Eğitim planlarının COVID-19 risk faktörleri ve koruyucu davranışlar (örn. COVID-19 semptomları, enfeksiyon önleme, hastalık bildirimi, öksürük görgü kuralları, yüze dokunmaktan kaçınma, uygun el yıkama ve KKE bakımı) hakkında işçilere güncel bilgi sağlama yönünde değiştirilmesi gerektiği, hem personelin psikolojik refahı hem de gıda güvenliği öğretimi ve temizlik uygulamalarını güçlendirmenin de aynı derecede önemli olduğu bildirilmiştir (CDC, 2020i; BSI Group, 2020). Bu sebeple birçok ülkede gıda çalışanlarının bahsedilen konular ile ilgili eğitilmeleri ve bilinçlendirilmeleri amaçlanmıştır.

$\mathrm{Bu}$ amaçla verilen eğitimlerde öncelikle önem verilen ilk aşama COVID-19'un temel semptomlarının $\left(\geq 37,5{ }^{\circ} \mathrm{C}\right.$ ateş, öksürük, nefes darlığı veya zorluğu, yorgunluk) (WHO, 2020i) anlatılması olmuştur. Gida sektöründe çalışan personellerin bahsedilen semptomlardan bir veya birkaçına sahip olması durumunda gida işletmesindeki yetkililere bildirimde bulunmaları, en kısa sürede test yaptırarak testin sonucuna ve enfeksiyonun şiddetine göre hastanede yatarak veya evde izole edilerek tedavi olmaları, işletmede temaslı olduğu diğer işçilerle ilgili gerekli prosedürlerin de uygulanması gerektiği bildirilmiştir (FAO ve WHO, 2020). DSÖ, tedavisi tamamlanıp iyileşen personel için işe dönüş politikası oluşturulması gerektiğini belirterek, teyit edilmiş bir vakanın semptomları düzeldiğinde 24 saat arayla en az iki negatif PCR testine tabi tutulmasını, testin mümkün olmadığ 1 durumda semptomlar düzeldikten 14 gün sonra izolasyondan çıkarılarak işe başlamasını önermiştir (WHO, 2020g).
HACCP (hazard analysis and critical control point-tehlike analizi ve kritik kontrol noktası)'e dayalı Gıda Güvenliği Yönetim Sistemleri güvenli g1da üretimini garanti etmektedir. $\mathrm{Bu}$ uygulamalar g1da kontaminasyonunu önlemekte, g1da riskini yönetmektedir ve bunların uygulanması düzenleyici kontrollere tabidir (Ceniti vd., 2021).

COVID-19 pandemisi sürecinde gida işletmeleri mevcut gida sağlığı kontrollerini uygulamaya ek olarak, COVID-19'dan kaynaklanan olası gıda güvenliği riskleri konusunda öncelikle DSÖ (WHO, 2020e) tarafından sonra da kendi ülkelerindeki yöneticiler tarafindan uyarılmış ve hangi ek önlemleri almaları gerektiği bildirilmiştir. Yetkili otoritelerce belirtilmiş, gıdayla ilişkili COVID-19 enfeksiyonunun oluşma riskinin azaltılması amacıyla işletmelerin ve gıda çalışanlarının yerine getirmesi gereken temel gida güvenliği uygulamaları Tablo 2'de özetlenmiştir (Ceniti vd., 2021; Nakat ve Bou-Mitri, 2021). Gida işletmeleri ve gıda çalışanları COVID-19'dan korunabildiği sürece gıdalar ve/veya gıda kaynaklı materyallerle enfeksiyonun yayılmasında aracılık etmeleri önlenmiş olacaktır.

COVID-19'un gıda veya gıda ambalajıyla ilişkili bulaşmasını destekleyen hiçbir kanıt olmasa da tesislerin virüs veya bakteri türünden bağımsız olarak hasta olan işçilerle ilişkili tüm riskleri kontrol etmesi, bu yüzden tesislerin ve gida ile temas eden yüzeylerin temiz ve steril olması gerektiği ifade edilmiştir (FDA, 2020b).

Tarladan sofraya kadar gıda tedarik zincirinin her aşamasında kritik önlemlerin alınması gerektiği belirtilmiş ve bu önlemler işçilerin tıbbi durumunun takibi (örn. hasta ise evde kalması) ve kişisel hijyeninin sağlanması, temiz çalışma ortamlarında ve yiyecek hazırlamada hijyenin sağlanması, teslimat sürecinde tedbirli olunması, yüzeylerin dezenfeksiyonu ve son olarak sosyal mesafenin sağlanması olarak gruplandırılmıştır. Ayrıca, üretimin 
son aşamalarına doğru sürece daha fazla insan dahil olduğu için daha fazla güvenlik önlemi alınması gerektiği belirtilmiştir (Rizou vd., 2020).
ABD Çalışma Bakanlığg Mesleki Güvenlik ve Sağlık İdaresi en etkili koruma önlemlerinin mühendislik ve idari kontroller ile KKE'lerin kullanılması olduğunu belirtmiştir (OSHA, 2020).

Tablo 2. COVID-19 Enfeksiyonu Riskinin Azaltılması Amacılla Yerine Getirilmesi Gereken Gıda Güvenliği Uygulamaları

\begin{tabular}{|c|c|}
\hline Gıda Güvenliği Uygulaması & Detaylar \\
\hline $\begin{array}{l}\text { Fiziksel } \\
\text { korunm }\end{array}$ & 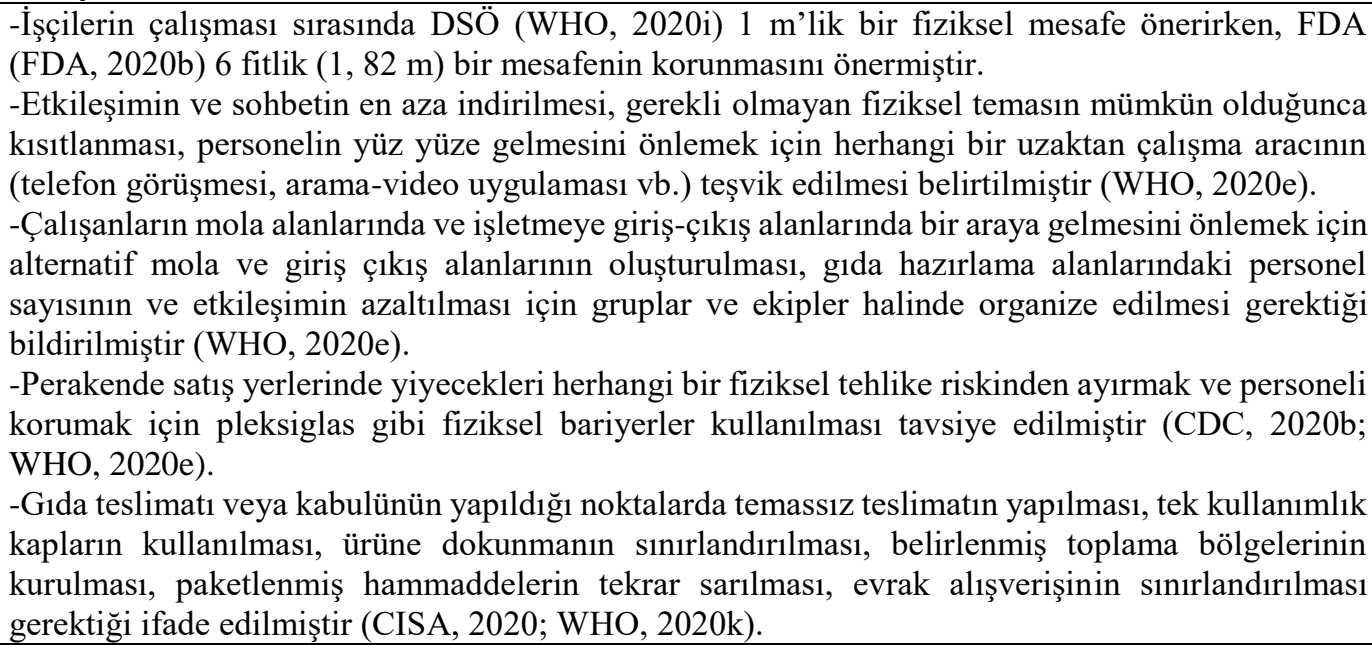 \\
\hline $\begin{array}{l}\text { Kişis } \\
\text { ekipr }\end{array}$ & $\begin{array}{l}\text {-Çalışanların özellikle yüz maskesi ve eldiven kullanımına dikkat etmesi ve sık sık değiştirmeleri } \\
\text { tavsiye edilmiştir (WHO, 2020e; FDA, 2020c). }\end{array}$ \\
\hline El hijyeninin sağlanması & $\begin{array}{l}\text {-Normal sabun ve } 20 \text { s süreyle akan ılık suyun yeterli bir el dezenfektanı olduğu, ek önlem olarak } \\
\text { \%60'lık alkol kullanılabileceği (Pittet vd., 2009), alkol bazlı el dezenfektanı kullanımının sık sık } \\
\text { teşvik edilmesi belirtilmiştir (WHO, 2020e). }\end{array}$ \\
\hline $\begin{array}{l}\text { Sanitasyonun/ } \\
\text { dezenfeksiyonun sağlanması }\end{array}$ & 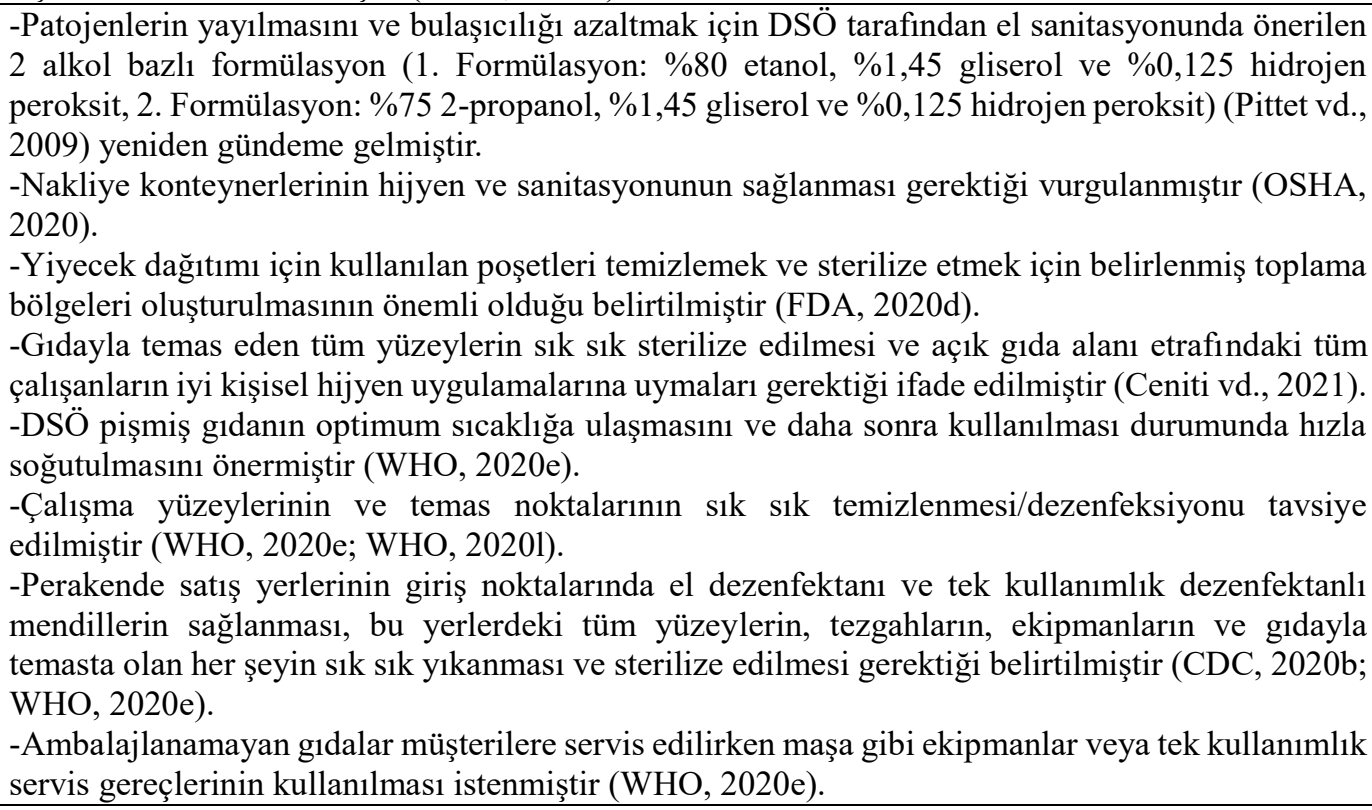 \\
\hline Çevre ve ortak alan yönetimi & $\begin{array}{l}\text {-Çalışanların işletme içinde düğmelere dokunmadan hareket etmesine izin verilmesi için otomatik } \\
\text { açılan kapıların kullanılması veya gıda güvenliği bölgelerini etkilemediği yerlerde kapıların } \\
\text { kaldırılması/açık tutulması tavsiye edilmiştir (WHO, 2020e; WHO, 20201). } \\
\text {-İnsan makine arayüzlerinin (klavye, düğme, ortak araçlar vb.) iki ayrı kullanıcı arasında } \\
\text { dezenfekte edilmesi gerektiği belirtilmiştir (WHO, 2020e; WHO, 20201). } \\
\text {-Boşluğun korunması ve yüz yüze etkileşimleri azaltmak için iş istasyonlarının yeniden } \\
\text { yapılandırılması önerilmiştir (WHO, 2020e; WHO, 20201). } \\
\text {-Perakende satış yerlerinde müşteri sepetlerinin temizlenmesinde sanitasyonun yerine } \\
\text { getirilmesinde veya hijyenik alışverişin sağlanmasında yardımcı olacak personelin atanmasının } \\
\text { faydalı olacağı bildirilmiştir (CDC, 2020b; WHO, 2020e). }\end{array}$ \\
\hline
\end{tabular}

Bunun yanında, gıda endüstrisinde ve yalnızca uygun kişisel hijyen ve el yıkama uygulamaları ile birlikte düzgün şekilde kullanılırsa, KKE'lerin hem çapraz enfeksiyonun (COVID-19) hem de çapraz kontaminasyonun (gıda güvenliği) yayılmasını azaltmada yardımcı olabileceği belirtilmiştir (WHO, 2020d). Gıda endüstrisi ile ilgili KKE’ler arasında yüz maskeleri, yüz siperleri, eldivenler, temiz üniformalar (sahada giyilir ve günlük olarak yıkanır), saç boneleri ve kapalı kaymaz iş ayakkabıları 
bulunmaktadır (BRCGS, 2020).

DSÖ tek kullanımlık eldivenlerin hiçbir zaman bir el yıkama yerine kullanılmamasını vurgulamış, SARS-CoV-2'nin işçilerin ellerinde olduğu gibi tek kullanımlık eldivenleri de aynı şekilde kontamine edebileceğini, çalışanların tek kullanımlık eldivenleri giymeden önce en az $20 \mathrm{~s}$ boyunca ellerini yıkaması gerektiğini belirtmiştir (WHO, 2020e).

Maske kullanımının esas olarak virüsü bilmeden yayabilecek asemptomatik işçiler için önemli ve özellikle SARS-CoV-2'nin bir solunum virüsü olması nedeniyle, belirtilen diğer KKE'lerden daha acil olduğu ifade edilmiştir (Nakat ve Bou-Mitri, 2021). DSÖ (WHO, 2020f) maske takmadan önce işçilerin ellerini yıkamalarını, hem ağız hem de burnun maske ile kapatılmasını, maskeye dokunduklarında ellerini yıkamalarını ya da dezenfekte etmelerini, maske nemlenip kirlendiğinde veya yırtıldığında değiştirmelerini tavsiye etmiştir.

İdeal olarak maskelerin her molada, tuvalete gidildiğinde veya çıkarılması için herhangi başka bir neden olduğunda değiştirilmesi, bir günden daha uzun süre tek bir maskenin takılmaması önerilmiştir (Angell, 2020). Maske veya yüz koruyucusunu çıkarırken dikkatli olunması, arkadan çıkarılması ve maskenin hemen kapalı bir kutuya atılarak ellerin yıkanması, yüz koruyucusu tekrar kullanılabilir durumda ise uygun bir yere bırakılarak dezenfekte edilmesi istenmiş̧ir (WHO, 2020g; CDC, 2020f). Tek kullanımlık önlükler çıkarılırken bağcıkları gevşetildikten sonra dış yüzeyinden değil iç yüzeyinden tutularak dikkatlice sıyrılması, iç kısmı dışa gelecek şekilde katlanarak atık kutusuna atılması gerektiği belirtilmiştir (CDC, 2020f).

Çalışanların, üretim hatları, alım ve paketleme alanları, numune alma ve kalite odaları ile konferans odaları, dinlenme odaları, soyunma odaları, tuvaletler, koridorlar ve girişler gibi ortak tesis alanlarında yakın temas nedeniyle enfekte olabileceği (IDFA, 2020) ve yakın temasin, COVID-19 pozitif bir bireyin yaklaşık $2 \mathrm{~m}$ (6 ft) içinde 15 dakikadan daha uzun süre olması anlamına geldiği bildirilmiştir (CDC, 2020g).

Temiz ve yıkanmış giysilerin COVID-19 için transfer vektör olarak kabul edilmediği (CDC, 2020h), virüs partikülleri ve hasta kişilerle temas etme olasıllığı olan giysiler için genel deterjanların kullanılması, en sicak sicaklık ayarında ve tam kuruma yapılması önerilmişsir (IDFA, 2020). Ayrıca CDC (2020h), temizlikle uğraşan kişilere; 1) virüsün havada yayılma olasılığını en aza indirmek için kirli çamaşırları sallamamalarını, 2) çamaşırların taşınmasında kullanılan her şeyi tipik temizlik ürünleriyle temizlemelerini ve dezenfekte etmelerini, 3) kirli maddelerle çalışırken tek kullanımlık eldiven giymelerini ve 4) eldivenleri çıkardıktan hemen sonra veya kirli eşyalara dokunduktan hemen sonra ellerini yıkamalarını tavsiye etmiştir.

Yetkili otoritelerce önerilen uygulamaların doğruluğunun kanıtlanması için bilimsel çalışmalar (Kratzel vd., 2020; Kampf vd., 2020; Chin vd., 2020) da yapılmıştır.

DSÖ tarafindan önerilen el ovma formülasyonlarının (Pittet vd., 2009) virisidal aktivite çalışması gerçekleştirildiğinde SARSCoV-2'nin $30 \mathrm{~s}$ sonra etkin bir şekilde inaktive edildiği bulunmuştur (Kratzel vd., 2020). Pişmiş gıdanın optimum sıcaklığa ulaşması gerektiği belirtilmiş (WHO, 2020e) ve koronavirüs enfeksiyonunun termal dezenfeksiyonla $\left(60{ }^{\circ} \mathrm{C} / 30\right.$ $\mathrm{dk}, 65{ }^{\circ} \mathrm{C} / 15 \mathrm{dk}$ ve $80{ }^{\circ} \mathrm{C} / 1 \mathrm{dk}$ ) büyük ölçüde (en az $4 \mathrm{log}$ ) azaltıldığ 1 (Kampf vd., 2020), SARS-CoV-2'nin 5 dk'llk 70 ${ }^{\circ} \mathrm{C}$ 'deki inkübasyon sıcaklığında inaktive edildiği bildirilmiştir (Chin vd., 2020). Yiyeceği $63{ }^{\circ} \mathrm{C}$ 'de 4 dakika pişirmenin, SARSCoV-2 tarafından bir gıda ürününün kontaminasyonunu 1000 kat azalttığı bildirilmiştir (ANSES, 2020).

Tüketicilerin SARS-CoV-2'nin paketlerin yüzeyinde hayatta kalma kabiliyetine ilişkin endişeleri, antiviral aktif paketleme özelliğine sahip polimer ve nano-bazlı biyopolimerlerin geliştirilmesine olan ilginin artmasına neden olmuştur. Antiviral özelliklere sahip biyopolimerlerin geliştirilmesi ve bunların gıda alanındaki uygulamaları açık bir araştırma alanı olmuştur (Olaimat vd,, 2020).

Nanomateryal kaplamaların veya bakır, gümüs ve çinko nanopartikül içeren filmlerin kullanımının, gıda ambalaj yüzeylerinin kontaminasyonunu önlemek ve dolayısıyla iletimini azaltmak için SARS-CoV-2'ye karşı bir potansiyele sahip olduğu bildirilmiştir (Sportelli vd., 2020). Van Doremalen vd. (2020) bakır yüzeylerde SARS-CoV-2'nin canlılı̆ıının azaldığını ve 2 saat içinde inaktive olduğunu doğrulamıştır.

\section{Sonuç}

Gıda işletmelerinde çalş̧an personellerin iyi hijyen uygulamaları kurallarını doğru şekilde uygulamaları halinde COVID-19'u gıda ve/veya gıda ile ilişkili maddelere/malzemelere bulaştırması mümkün görülmemektedir. Buna ek olarak pandemi sürecinde COVID-19'a özel hijyen ve sanitasyon uygulamalarına gereken titizlik gösterilirse gıda sektörü çalışanları pandeminin yayılımının önlenmesi ve pandemiyle mücadelede üzerlerine düşen görevi yerine getirmiş olacaklardır. SARS-CoV-2 muhtemelen uzun bir süre daha devam edeceğinden gıda çalışanları "normal hijyen uygulamaları"nı "yeni normaller"e dönüştürmek zorundadırlar. Araştırmacılar gıda aracılığıyla COVID-19 enfeksiyonunun oluşumunda etkili olabilecek faktörlerin detaylı tespiti, alınması gereken özel gıda güvenliği önlemlerinin etkinliği, ticari gıda ürünlerinin SARSCoV-2 kontaminasyonuna karşı korunabilmesi için antiviral işleme ve muhafaza yöntemlerinin geliştirilmesi konusunda çalışmalarını sürdürmelidirler. Başka ortaya çıkma ihtimali olabilecek viral enfeksiyonların gida, gidayla temas eden madde/malzeme, gıda işleme tesisi ve gıda çalışanı aracılığıyla yayılımının önüne geçilmesi konusuna da aynı önem verilmelidir.

\section{Kaynakça}

Aboubakr, H.A., Sharafeldin, T.A., Goyal, S.M. (2020). Stability of SARS-CoV-2 and other coronaviruses in the environment and on common touch surfaces and the influence of climatic conditions: a review. Transboundary and Emerging Diseases, 68(2), 296-312.

Angell, S. (2020). Face covering guidance. California Department of Public Health. https://www.cdph.ca.gov/Programs/CID/DCDC/Pages/FaceCoverings-Guidance.aspx (Erişim tarihi: 20.05.2021).

ANSES (2020). ANSES's recommendations on food, shopping and cleaning. The French Agency for Food, Environmental and Occupational Health \& Safety. https://www.anses.fr (Erişim tarihi: 20.05.2021).

AP News, (2021). WHO urges pause in market sale of captured live wild animals. The Associated Press. 
https://apnews.com/article/animals-health-coronaviruspandemic-infectious-diseases-united-nations820f6195996181264a5611f40ab04b2f (Erişim tarihi: 20.05.2021).

Artiga, S., Rae, M. (2020). The COVID-19 outbreak and food production workers: who is at risk? Kaiser Family Foundation. https://www.kff.org/coronavirus-covid-19/issuebrief/the-covid-19-outbreakand-food-production-workerswho-is-at-risk/ (Erişim tarihi: 20.05.2021).

BBC (2020). Coronavirus: virus outbreaks push Germany to clean up abattoirs. British Broadcasting Corporation. https://www.bbc.com/news/world-europe-52738356 (Erişim tarihi: 20.05.2021).

BBC News (2021). Covid: Wuhan'da incelemeler yapan WHO heyeti koronavirüsün kökeniyle ilgili ne dedi? British Broadcasting Corporation News. https://www.bbc.com/turkce/haberler-dunya-55995003 (Erişim tarihi: 20.05.2021).

Bienkov, A. (2020). Coronavirus: loss of smell and taste may be hidden symptom of COVID19-business insider. https://www.businessinsider.com/coronavirussymptoms-loss -of-smell-taste-covid-19-anosmia-hyposmia-2020-3 (Erişim tarihi: 20.05.2021).

Blondin-Brosseau, M., Harlow, J., Doctor, T., Nasheri, N. (2020). Examining the persistence of human coronaviruses on fresh produce. bioRxiv.

Bondad-Reantaso, M.G., Mackinnon, B., Bin, H., Jie, H., TangNelson, K., Surachetpong, W., Alday-Sanz, V., Salman, M., Brun, E., Karunasagar, I., et al. (2020). SARS-CoV-2 (the cause of COVID-19 in humans) is not known to infect aquatic food animals nor contaminate their products. Asian Fisheries Science, 33(1), 74-78.

Bosch, A., Gkogka, E., Le Guyader, F.S., Loisy-Hamon, F., Lee, A., van Lieshout, L., Marthi, B., Myrmel, M., Sansom, A., Schultz, A.C., et al. (2018). Foodborne viruses: detection, risk assessment, and control options in food processing. International of Journal of Food Microbiology, 285, 110-128.

BRCGS (2020). BRCGS guidance document: managing food safety during COVID-19. BRC Global Standards. https://www.brcgs.com/media/2082504/food-safety-covid19-guideline-unlocked.pdf (Erişim tarihi: 20.05.2021).

BSI Group (2020). Safe working during the Covid-19 pandemicgeneral guidelines for organizations version 1. BSI Flex. https://www.bsigroup.com/en-GB/topics/novel-coronaviru scovid-19/covid-19-guidelines/ (Erişim tarihi: 20.05.2021).

BfR (2020). Can the new type of coronavirus be transmitted via food and objects?. Bundesinstitut für Risikobewertung. https://www.bfr.bund.de/en/can_the_new_type_of_coronavir us_be_transmitted_via_food_and_objects_-244090.html (Erişim tarihi: 20.05 .2021$)$.

CDC (2020a). Symptoms of coronavirus. The Centers for Disease Control and Prevention. https://www.cdc.gov/coronavirus/2019-ncov/symptomstesting/symptoms.html (Erişim tarihi: 20.05.2021).

CDC (2020b). Interim guidelines for collecting, handling, and testing clinical specimens from persons for coronavirus disease 2019 (COVID-19). The Centers for Disease Control and Prevention. https://www.cdc.gov/coronavirus/2019ncov/lab/guidelines-clinical-specimens.html (Erişim tarihi: 20.05.2021).

CDC (2020c). Public health guidance for potential COVID-19 exposure associated with travel. The Centers for Disease Control and

Prevention. https://www.cdc.gov/coronavirus/2019-ncov/php/riskassessment.html (Erişim tarihi: 20.05.2021).

CDC (2020d). Protecting seafood processing workers from COVID-19. The Centers for Disease Control and Prevention. https://www.cdc.gov/coronavirus/2019-

ncov/community/guidance-seafood-processing.html (Erişim tarihi: 20.05.2021).

CDC (2020e). Agriculture workers and employers. The Centers for Disease Control and Prevention. https://www.cdc.gov/coronavirus/2019ncov/community/guidance-agricultural-workers.html (Erişim tarihi: 20.05.2021).

CDC (2020f). Guidance for the selection and use of personal protective equipment (PPE) in healthcare settings. The Centers for Disease Control and Prevention. https://www.cdc.gov/hai/pdfs/ppe/ppeslides6-29-04.pdf (Erişim tarihi: 20.05.2021).

CDC (2020g). Interim US guidance for risk assessment and public health management of persons with potential coronavirus disease 2019 (COVID-19) exposures: geographic risk and contacts of laboratory-confirmed. The Centers for Disease Control and Prevention. https://www.cdc.gov/coronavirus/2019-ncov/hcp/guidancerisk-assesment-hcp.html (Erişim tarihi: 20.05.2021).

CDC (2020h). Cleaning and disinfecting your facility. The Centers for Disease Control and Prevention https://www.cdc.gov/coronavirus/2019-

ncov/community/disinfecting-building-facility.html (Erişim tarihi: 20.05.2021).

CDC (2020i). Meat and poultry processing workers and employers. The Centers for Disease Control and Prevention. https://www.cdc.gov/coronavirus/2019-

ncov/community/organizations/meat-poultry-processingworkers-employers.html (Erişim tarihi: 20.05.2021).

Ceniti, C., Tilocca, B., Britti, D., Santoro, A., Costanzo, N. (2021). Food safety concerns in "COVID-19 era". Microbiology Research, 12, 53-68. https://doi.org/10.3390/microbiolres12010006

Chin, A.W.H., Chu, J.T.S., Perera, M.R.A., Hui, K.P.Y., Yen, H.L., Chan, M.C.W., Peiris, M., Poon, L.L.M. (2020). Stability of SARS-CoV-2 in different environmental conditions. Lancet Microbe, 1, e10.

CISA (2020). Guidance on the essential critical infrastructure workforce: advisory memorandum on ensuring essential critical infrastructure workers' ability to work during The Covid-19 response. Cybersecurity and Infrastructure Security Agency.

https://www.cisa.gov/sites/default/files/publications/ECIW 4.0_Guidance_on_Essential_Critical_Infrastructure_Worker S_Final3_508_0.pdf (Erişim tarihi: 20.05 .2021 ).

Costa, S., Posteraro, B., Marchetti, S., Tamburrini, E., Carducci, B., Lanzone, A., Valentini, P., Buonsenso, D., Sanguinetti, M., Vento, G., Cattani, P. (2020). Excretion of SARS-CoV-2 in human breast milk. Clinical Microbiology and Infection, 26, 1430-1432.

Decaro, N., Mari, V., Campolo, M., Lorusso, A., Camero, M., Elia, G., Martella, V., Cordioli, P., Enjuanes, L., Buonavoglia, C. (2009). Recombinant canine coronaviruses related to transmissible gastroenteritis virus of swine are circulating in dogs. Journal of Virology, 83(3), 1532-1537.

Douglas, L. (2020). Mapping Covid-19 outbreaks in the food system, food \& environment reporting network. 
https://thefern.org/2020/04/mapping-covid-19-in-meat-andfood-processing-plants/ (Erişim tarihi: 20.05.2021).

Dyal, J.W. (2020). COVID-19 among workers in meat and poultry processing facilities-19 states, April 2020. MMWR. Morbidity and Mortality Weekly Report, 69(18), 557-561.

EC (2020). Covid-19 and food safety, questions and answers. European Commission Directorate-General for Health and Food Safety. Brussel, België, 12p.

EFSA (2020). Coronavirus: no evidence that food is a source or transmission route. European Food Safety Authority. https://www.efsa.europa.eu/en/news/coronavirus-noevidence-food-source-or-transmission-route (Erişim tarihi: 20.05.2021).

Evrensel (2020a). Gıda-İş, fabrikalarda alınmayan koronavirüs önlemlerini raporlaştırdı. Evrensel. https://www.evrensel.net/haber/400611/gida-is-fabrikalardaalinmayan-koronavirus-onlemlerini-raporlastirdi (Erişim tarihi: 20.05.2021).

Evrensel (2020b). Gıda-İş Sendikası: Gıda işçileri risk altında çalışıyor.

Evrensel. https://www.evrensel.net/haber/402586/gida-is-sendikasigida-iscileri-risk-altinda-calisiyor (Erişim tarihi: 20.05.2021).

FAO ve WHO (2020). COVID-19 and food safety: guidance for food businesses: interim guidance. Food and Agriculture Organization of the United Nations-World Health Organization, WHO reference number: WHO/2019nCoV/Food_Safety/2020.1.

https://apps.who.int/iris/bitstream/handle/10665/331705/W HO-2019-nCoV-Food_Safety-2020.1-eng.pdf (Erişim tarihi: 20.05.2021).

FDA (2020a). Coronavirus disease 2019 (COVID-19) and the food supply chain. U.S. Food and Drug Administration. https://www.fda.gov/food/food-safety-duringemergencies/food-safety-and-coronavirus-disease-2019covid-19 (Erişim tarihi: 20.05.2021).

FDA (2020b). Food safety and the coronavirus disease 2019 (COVID-19). U. S. Food and Drug Administration. https://www.fda.gov/food/food-safety-duringemergencies/food-safety-and-coronavirus-disease-2019covid-19 (Erişim tarihi: 20.05.2021).

FDA (2020c). Best practices for retail food stores, restaurants, and food pick-up/delivery services during the COVID-19. U. S. Food and Drug Administration. https://www.fda.gov/food/food-safety-duringemergencies/best-practices-retail-food-stores-restaurantsand-foodpick-updelivery-services-during-covid19\#employeehealth (Erişim tarihi: 20.05.2021).

FDA (2020d). Food safety and availability during the coronavirus pandemic. U. S. Food and Drug Administration. https://www.fda.gov/consumers/consumer-updates/foodsafety-and-availability-during-coronavirus-pandemic (Erişim tarihi: 20.05.2021).

Gulland, A. (2020). Revealed: why meat processing plants are the ideal incubator of the coronavirus. The Telegraph. https://www.telegraph.co.uk/global-health/science-anddisease/revealed-meat-processing-plantsideal-incubatorcoronavirus/ (Erişim tarihi: 20.05.2021).

Guo, Z.D., Wang, Z.Y., Zhang, S.F., Li, X., Li, L., Li, C., Cui, Y., Fu, R.B., Dong, Y.Z., Chi, X.Y., et al. (2020). Aerosol and surface distribution of severe acute respiratory syndrome coronavirus 2 in hospital wards, Wuhan, China, 2020. Emerging Infectious Diseases, 26(7), 1586-1591.
Han, J., Zhang, X., He, S., Jia, P. (2021). Can the coronavirus disease be transmitted from food? A review of evidence, risks, policies and knowledge gaps. Environmental Chemistry Letters, 19, 5-16.

Harbourt, D.E., Haddow, A.D., Piper, A.E., Bloomfield, H., Kearney, B.J., Fetterer, D., Gibson, K., Minogue, T. (2020). Modeling the stability of severe acute respiratory syndrome coronavirus 2 (SARS-CoV-1 2) on skin, currency, and clothing. PLOS Neglected Tropical Diseases, 14, e0008831.

Hasoksuz, M., Alekseev, K., Vlasova, A., Zhang, X., Spiro, D., Halpin, R., Wang, S., Ghedin, E., Saif, L.J. (2007). Biologic, antigenic, and full-length genomic characterization of a bovine-like coronavirus isolated from a giraffe. Journal of Virology, 81(10), 4981-4990.

Hindson, J. (2020). COVID-19: faecal-oral transmission? Nature Reviews Gastroenterology and Hepatology, 17, 259.

Hu, Y., Shen, L., Xu, Z., Zhou, J., Zhou, H. (2020). SARS-CoV-2 may persist in digestive tract longer than respiratory tract. Preprints, 2020020354.

IDFA (2020). Emergency prevention measures to achieve physical (social) distancing in food manufacturing facilities as related to COVID-19. International Dairy Food Association. $\quad$ https://www.idfa.org/wordpress/wpcontent/uploads/2020/04/2020-03-31-Emergency-

Preventions-Measures-for-Physical-Distancing-in-FoodManufacturing-as-Related-to-COVID-19.pdf (Erişim tarihi: 20.05.2021).

ISDH (2020). COVID-19 food safety guidelines. Indiana State Department of Health, Epidemiology Research Center.

https://www.hamiltoncounty.in.gov/DocumentCenter/View/1476 2/Food-Safety-Guidelines-COVID19-ISDH?bidId= $($ Erişim tarihi: 20.05.2021).

Kampf, G., Voss, A., Scheithauer, S. (2020). Inactivation of coronaviruses by heat. Journal of Hospital Infection, 105(2), 348-349.

Kaur, G. (2020). Meat plants become hotspots for Covid-19 across the World. https://www.grainmart.in/news/meatplants-become-hotspotsfor-covid-19-across-the-world/ (Erişim tarihi: 20.05.2021).

Kratzel, A., Steiner, S., Todt, D., V'kovski, P., Brueggemann, Y., Steinmann, J., Steinmann, E., Thiel, V., Pfaender, S. (2020). Temperature-dependent surface stability of SARS-CoV-2. Journal of Infection, 81, 452-482.

Lam, S.D., Bordin, N., Waman, V.P., Scholes, H.M., Ashford, P., Sen, N., van Dorp, L., Rauer, C., Dawson N.L., Pang, C.S.M., et al. (2020). SARS-CoV-2 spike protein predicted to form complexes with host receptor protein orthologues from a broad range of mammals. Scientific Reports, 10, 16471.

Lam, T.T.Y., Jia, N., Zhang, Y.W., Shum, M.H.H., Jiang, J.F., Zhu, H.C., Tong, Y.G., Shi, Y.X., Ni, X.B., Liao, Y.S., et al. (2020). Identifying SARS-CoV-2-related coronaviruses in Malayan pangolins. Nature, 583, 282-285.

Leung, N.H.L., Chu, D.K.W., Shiu, E.Y.C., Chan, K.H., McDevitt, J.J., Hau, B.J.P., Yen, H.L., Li, Y., Ip, D.K.M., Peiris, J.S.M., et al. (2020). Respiratory virus shedding in exhaled breath and efficacy of face masks. Nature Medicine, 26, 676-680.

Matson, M.J., Yinda, C.K., Seifert, S.N., Bushmaker, T., Fischer, R.J., van Doremalen, N., Lloyd-Smith, J.O., Munster, V.J. (2020). Effect of environmental conditions on SARS-CoV-2 stability in human nasal mucus and sputum, Emerging Infectious Diseases, 26(7), 2276-2278. 
Middleton, J., Reintjes, R., Lopes, H. (2020). Meat plants-a new front line in the Covid-19 pandemic. British Medical Journal, $370, \mathrm{~m} 2716$.

Mungroo, M.R., Khan, N.A., Siddiqui, R. (2020). Novel coronavirus: current understanding of clinical features, diagnosis, pathogenesis, and treatment options. Pathogens, 9(4), 297. doi: 10.3390/pathogens9040.

Nakat, Z.; Bou-Mitri, C. (2021). COVID-19 and the food industry: readiness assessment. Food Control, 121, 107661.

NEHA (2020). COVID-19 and food safety. National Environmental Health Association. https://www.neha.org/covid-19 (Erişim tarihi: 20.05.2021).

Niederwerder, M.C., Hesse, R.A. (2018). Swine enteric coronavirus disease: a review of 4 years with porcine epidemic diarrhoea virus and porcine deltacoronavirus in the United States and Canada. Transboundary and Emerging Diseases, 65(3), 660-675.

Oakenfull, R. J., Wilson, A. J. (2020). Qualitative risk assessment: what is the risk of food or food contact materials being a source or transmission route of SARS-CoV-2 for UK consumers?. Food Standards Agency, London, UK.

Olaimat, A. N., Shahbaz, H. M., Fatima, N., Munir, S., Holley, R. A. (2020). Food safety during and after the era of Covid-19 pandemic. Frontiers in Microbiology, 11, 1854.

OSHA (2020). Guidance on preparing workplaces for COVID-19. Occupational Safety and Health Administration. https://www.osha.gov/Publications/OSHA3990.pdf (Erişim tarihi: 20.05.2021).

Pang, X., Ren, L., Wu, S., Ma, W., Yang, J., Di, L., Li, J., Xiao, Y., Kang, L., Du, S., et al. (2020). Cold-chain food contamination as the possible origin of Covid-19 resurgence in Beijing. National Science Review, 7, 1861-1864.

Pastorino, B., Touret, F., Gilles, M., de Lamballerie, X., Charrel, R.N. (2020). Prolonged infectivity of SARS-CoV-2 in fomites. Emerging Infectious Diseases, 26(7), 2256-2257.

Pittet, D., Allegranzi, B., Boyce, J. (2009). The World Health Organization guidelines on hand hygiene in health care and their consensus recommendations. Infection Control \& Hospital Epidemiology, 30(7), 611-622.

Pung, R., Chiew, C.J., Young, B.E., Chin, S., Chen, M.I.C., Clapham, H.E., Cook, A.R., Maurer-Stroh, S., Toh, M.P.H.S., Poh, C., et al. (2020). Investigation of three clusters of COVID-19 in Singapore: implications for surveillance and response measures. Lancet, 395, 1039-1046.

Riddell, S., Goldie, S., Hill, A., Eagles, D., Drew, T.W. (2020). The effect of temperature on persistence of SARS-CoV-2 on common surfaces. Virology Journal, 17(1), 145.

Rizou, M., Galanakis, I.M., Aldawoud, T.M., Galanakis, C.M. (2020). Safety of foods, food supply chain and environment within the COVID-19 pandemic. Trends in Food Science \& Technology, 102, 293-299.

Shenzhen Goverment, (2020). COVID-19 virus found in imported frozen chicken Wings_Notices-Shenzhen Government.

http://www.sz.gov.cn/en_szgov/news/notices/content/post_8 000285.html (Erişim tarihi: 20.05.2021).

Van Doorn, A.S., Meijer, B., Frampton, C.M.A., Barclay, M.L., de Boer, N.K.H. (2020). Systematic review with metaanalysis: SARS-CoV-2 stool testing and the potential for faecal-oral transmission. Alimentary Pharmacology and Therapeutics, 52(8), 1276-1288.

Van Doremalen, N., Bushmaker, T., Morris, D.H., Holbrook, M.G., Gamble, A., Williamson, B.N., Tamin, A., Harcourt,
J.L., Thornburg, N.J., Gerber, S.I., Lloyd-Smith, J.O., de Wit, Emmie, Munster, V.J. (2020). Aerosol and surface stability of HCoV-19 (SARS-CoV-2) compared to SARS-CoV-1. The New England Journal of Medicine, 382, 1564-1567.

Velebit, B., Djordjevic, V., Milojevic, L., Babic, M., Grkovic, N., Jankovic, V., Yushina, Y. (2019). The common foodborne viruses: a review. IOP Conference Series: Earth and Environmental Science, 333, 012110. doi: 10.1088/17551315/333/1/012110.

Walls, A.C., Park, Y.J., Tortorici, M.A., Wall, A., McGuire, A.T., Veesler, D. (2020). Structure, function, and antigenicity of the SARSCoV-2 spike glycoprotein. Cell, 181(2), 281-92. doi: 10.1016/j.cell.2020.02.058.

Waltenburg, M.A., Victoroff, T., Rose, C.E., Butterfield, M., Jervis, R.H., Fedak, K.M., Gabel, J.A., Feldpausch, A., Dunne, E.M., Austin, C. et al. (2020). Update: COVID-19 among workers in meat and poultry processing facilitiesUnited States, April-May 2020. MMWR. Morbidity and Mortality Weekly Report, 69 (27), 887-92. doi: 10.15585/mmwr.mm6927e2.

WHO (2020a). Coronavirus disease 2019 (COVID-19) situation report-32. World Health Organization. https://www.who.int/docs/defaultsource/coronaviruse/situation-reports/20200221-sitrep-32covid-19.pdf?sfvrsn=4802d089_2 (Erişim tarihi: 20.05.2021).

WHO (2020b). Coronavirus disease (COVID-19): how is it transmitted? World Health Organization. https://www.who.int/news-room/q-adetail/q-a-how-is-covid19-transmitted (Erişim tarihi: 20.05.2021).

WHO (2020c). Global surface sampling of coronavirus disease (COVID-19): a practical "how to" protocol for health care and public health professionals. World Health Organization. https:/www.who.int/publications/i/item/surface-samplingof-coronavirus-disease-(-covid-19)-a-practical-how-toprotocol-for-health-care-and-public-health-professionals (Erişim tarihi: 20.05.2021).

WHO (2020d). Rational use of personal protective equipment for coronavirus disease (COVID-19) and considerations during severe shortages. World Health Organization. https://www.who.int/publications-detail/rational-use-ofpersonal-protective-equipment-for-coronavirus-disease(covid-19)-and-considerations-during-severe-shortages (Erişim tarihi: 20.05.2021).

WHO (2020e). World Health Organization COVID-19 and food safety: guidance for food businesses: interim guidance. World Health

Organization. https://www.who.int/publications/i/item/covid-19-and-foodsafety-guidance-for-food-businesses (Erişim tarihi: 20.05.2021).

WHO (2020f). Coronavirus disease (COVID-19) advice for the public: when and how to use masks. World Health Organization.

https://www.who.int/emergencies/diseases/novelcoronavirus-2019/advice-for-public/when-and-how-to-usemasks (Erişim tarihi: 20.05.2021).

WHO (2020g). Considerations in the investigation of cases and clusters of COVID-19. World Health Organization. https://www.who.int/publications-detail/considerations-inthe-investigation-of-cases-and-clustersof-covid-19 (Erişim tarihi: 20.05.2021).

WHO (2020h). Coronavirus disease (Covid-19) outbreak: rights, roles and responsibilities of health workers, including key 
considerations for occupational safety. World Health Organization.

https://www.who.int/publications/i/item/coronavirus-

disease-(covid19)-outbreak-rights-roles-and-responsibilitiesof-health-workers-including-key-considerations-foroccupational-safety-andhealth (Erişim tarihi: 20.05.2021).

WHO (2020i). Q\&A on coronaviruses (COVID-19). World Health Organization. https://www.who.int/news-room/q-adetail/q-acoronaviruses (Erişim tarihi: 20.05.2021).

WHO (2020j). WHO recommendations to reduce risk of transmission of emerging pathogens from animals to humans in live animal markets. World Health Organization. https://www.who.int/health-

topics/coronavirus/whorecommendations-to-reduce-risk-oftransmission-of-emerging-pathogens-from-animals-tohumans-in-live-animal-markets (Erişim tarihi: 20.05.2021).

WHO (2020k). Laboratory testing for 2019 novel coronavirus (2019-nCoV) in suspected human cases. World Health Organization.

https://www.who.int/publications/i/item/10665-331501

(Erişim tarihi: 20.05.2021).

WHO (20201). Getting your workplace ready for COVID-19: how COVID-19 spreads. World Health Organization. https://www.who.int/publications/m/item/getting-yourworkplace-ready-for-covid-19-how-covid-19-spreads (Erişim tarihi: 20.05.2021).
Wong, S.H., Lui, R.N.S., Sung, J.J.Y. (2020). Covid-19 and the digestive system. Journal of Gastroenterology and Hepatology, 35 (5), 744-748. doi: 10.1111/jgh.15047.

Wu, Y., Guo, C., Tang, L., Hong, Z., Zhou, J., Dong, X., Yin, H., Xiao, Q., Tang, Y., Qu, X., et al. (2020). Prolonged presence of SARS-CoV-2 viral RNA in faecal samples. The Lancet Gastroenterology \& Hepatology, 5(5), 434-435.

Xiao, F., Tang, M., Zheng, X., Liu, Y., Li, X., Shan, H. (2020). Evidence for gastrointestinal infection of SARS-CoV-2. Gastroenterology, 158(6), 1831-1833. doi: $10.1053 /$ j.gastro.2020.02.055.

Yannas, F. (2020). FDA's perspective on food safety and availability during and beyond COVID-19. https://www.fda.gov/food/conversations-expertsfoodtopics/fdas-perspective-food-safety-and-availability-duringand-beyond-covid19 (Erişim tarihi: 20.05.2021).

Ziady, H., Halasz, S., Kottasova, I. (2020). The giant meatpacking company at the heart of Germany's new coronavirus hotspot. CNN (Cable News Network) Business. https://edition.cnn.com/2020/06/22/business/meat-plantgermany-coronavirus-outbreak/index.html (Erişim tarihi: 20.05.2021). 